\title{
Analisis Performa Generator Set Diesel PLTD Terhadap Perubahan Beban di Pusat Pengembangan Sumber Daya Manusia Minyak dan Gas Bumi
}

\author{
Wahyu Hayatullah', Sandhika Putra Pratama', Fajar Muhammad Yakut ', Malik Rachman \\ Muzaini ${ }^{1}$, Mukhamad Faeshol Umam² \\ 1 Universitas Muhammadiyah,Surakarta \\ 2 Pusat Pengembangan SDM Minyak dan Gas Bumi, Cepu
}

\begin{abstract}
Abstrak 1826 kW. Data pengukuran di lapangan menunjukkan beban aktif sebesar $314.29 \mathrm{~kW}$ atau 392.86 kVA yang dilayanai oleh 1 genset yang beroperasi. Konsumsi bahan bakar sebesar 1140 liter solar per 24 jam dan 0.2844 liter/kWh. Dengan demikian mesin diesel PLTD masih bekerja dengan optimal karena beban yang ditanggung tidak melebihi batas daya maksimal. Faktor utama optimalnya kerja mesin ini yakni perawatan preventive dan maintenance harian serta setiap 250 jam.

Kata kunci: Generator set, Beban, Daya, Maintenance
\end{abstract}

Generator set di pembangkit listrik tenaga diesel (PLTD) di Pusat Pengembangan Sumber Daya Manusia Minyak dan Gas Bumi (PPSDM Migas) merupakanpembangkit listrik utama untuk menyuplai daya ke kilang dan utilitasnya. Dalam pengoperasiaannya, generator set mengalami variasi energi yang dibangkitkanberbanding lurus terhadap beban-bebannya. Dalam penulisan ini, peneliti ingin memahami fenomena yang terjadi pada generator set KTA 38G5. Metode yang digunakan adalah observasi lapangan dengan mengambil data langsung. Peneliti juga mengamati dan mempelajari hal-hal yang berkaitan dengan objek penelitian.

Hasil penelitian ini menunjukkan bahwa potensi beban total yang tercatat di lapangan sebesar

INFORMASI NASKAH

Diterima: 14 Januari 2021

Direvisi: 28 Januari 2021

Diterima: 24 Maret 2021

Terbit: 24 April 2021

Email korespondensi: wahyuhayatullah@gmail.com

Laman daring:

https://doi.org/10.37525/sp/2021-1/271

\section{Pendahuluan}

Kebutuhan energi listrik di PPSDM Migas sebagian besar disuplai oleh Perusahaan Listrik Negara (PLN) dan sebagian lagi disuplai oleh PLTD mandiri berkapasitas 2000 kVA. Kebutuhan energi listrik yang disuplai oleh PLTD ini antara lain unit pengolahan minyak bumi (kilang) dan fasilitas pendukungnya (utilitas) termasuk unit pengolahan air, pengolahan udara bertekanan dan air pendingin. Listrik ini harus selalu tersedia pada saat dibutuhkan oleh unit-unit. Sedangkan besar kecilnya beban serta perubahannya tergantung pada kebutuhan unit tersebut akan 
listrik. Besar beban PLTD berubah-ubah sepanjang waktu dalam kaitannya melayani beban sistem. Hal ini mengakibatkan jumlah konsumsi bahan bakar per satuan waktu juga berubahubah menurut waktu. Oleh karena itu, perlu adanya penjadwalan unit-unit pembangkit untuk mensuplai beban sehingga penggunaan bahan bakar bisa efisien dan perawatan berkala (preventif) bisa dilakukan sesuai jadwal.

\section{Tinjauan Pustaka}

Menurut Wijana, M.,Triadi, A. A., \& Anwar, L.S. (2016), "Pembangkit Listrik Tenaga Diesel (PLTD) ialah pembangkit listrik yang menggunakan mesin diesel sebagai penggerak mula (prime mover). Prime mover merupakan peralatan yang mempunyai fungsi menghasilkan energi mekanis yang diperlukan untuk memutar rotor generator. Mesin diesel sebagai penggerak mula PLTD berfungsi menghasilkan tenaga mekanis yang dipergunakan untuk memutar rotor generator. Pada mesin diesel energi bahan bakar diubah menjadi energi mekanik dengan proses pembakaran di dalam mesin itu sendiri. Yang dimaksud dengan unit PLTD adalah kesatuan peralatan-peralatan utama dan alat-alat bantu serta perlegkapannya yang tersusun dalam hubungan kerja, membentuk system untuk mengubah energi yang terkandung di dalam bahan bakar minyak menjadi tenaga mekanis dengan menggunakan mesin diesel sebagai penggerak utamanya dan seterusnya tenaga mekanis tersebut oleh generator diubah menjadi tenaga listrik".

Sementara itu jika dikaitkan dengan bahan bakar, menurut Badaruddin, B., dan Hardiansyah, F. (2015), Pemakaian bahan bakar dapat diperkirakan dengan menghitung total daya beban yang digunakan peralatan listrik, maka konsumsi generator set dapat diperkirakan. Konsumsi bahan bakar pada generator pengerak motor bensin dan pengerak motor diesel dapat dilihat perbandingannya dengan rumus ini. Konsumsi bahan bakar spesifik generator atau sering disebut Spesific Fuel Consumption (SFC) merupakan pembagian jumlah konsumsi bahan bakar dengan daya output. Pada saat perhitungan perkiraan SFC, daya output bergerak sama dengan daya bebannya, kenyataannya tidak, disitu ada factor Efisiensinya"

Dilanjut dalam jurnal tersebut nilai rata-rata dari otto dan diesel engine sebagai berikut:

- Otto (gasoline) engine: 273-227 g/kw/hr, dengan nilai rata-rata $250 \mathrm{~g} / \mathrm{kw} / \mathrm{hr}$

- Diesel engine: 209-178 g/kw/hr, dengan nilai rata-rata $194 \mathrm{~g} / \mathrm{kw} / \mathrm{hr}$

Sedangkan berat jenis suatu bahan bakar tergantung pada temperature dan kandungannya, secara umum dapat diambil nilai rata-rata adalah:

- Bensin 0,745 kg/l

- Solar 0,832 kg/l

Sehingga digunakan rumus di bawah ini:

$$
\mathrm{S}=\mathrm{K} \times \mathrm{P} \times \mathrm{T}
$$

Dimana,

S : Specific Fuel Consumption 
$\mathrm{K}: 0.2$ (Faktor ketetapan konsumsi solar per kilowatt per jam)

$P$ : Daya Genset $(k \vee A)$

T : Waktu

Sedangkan untuk mencari konsumsi bahan bakar dalam satuan liter menggunakan persamaan:

\section{Metode Penelitian}

Dalam melakukan kegiatan kerja praktik ini, penulis menggunakan metode kualitatif dan observasi lapangan. Dimana metode kualitatif ini adalah penelitian yang bermaksud untuk memahami fenomena tentang apa yang di teliti dalam hal ini adalah generator set KTA 38G5. Kemudian, dengan metode observasi lapangan, peneliti mengamati dan mempelajari hal-hal yang berkaitan dengan objek penelitian.

Sedangkan untuk pengumpulan data dan pengerjaaan laporan kerja praktik ini meliputi:

1. Kepustakaan

Telaah kepustakaan ini merupakan studi pendahuluan yang bertujuan untuk mencari data tentang masalah penelitian. Tahap ini sangat penting karena merupakan dasar penyusunan kerangka teoritis. Kerangka teoritis ini berguna untuk menuntun pemecahan masalah. Dalam hal ini telaah kepustakaan peneliti lakukan dengan mempelajari dokumen atau hasil penelitian terdahulu, mempelajari berbagai buku yang berhubungan dengan masalah penelitian, dan mempelajari informasi yang diperoleh dari internet.

\section{Pengamatan langsung}

Pemgamatan langsung dilakukan tanpa menggunakan peralatan khusus. Jadi perencang langsung mengamati dan mencatat segala sesuatu yang diperlukan pada saat terjadinya proses. Hal-hal yang didapat dalam pengamatan langsung ini peneliti mendapatkan data proses penyedia daya dari generator set KTA 38G5 untuk menyuplai daya-daya yang merupakan beban dari generator set itu sendiri. Selain itu peneliti juga melakukan pengamatan terhadap mesin generator set dan juga proses pemeliharaan dan perawatan.

\section{Hasil Penelitian dan Pembahasan}

\section{A. Pembangkit Listrik tenaga Diesel (PLTD)}

PLTD PPSDM Migas memiliki empat generator set yang siap untuk menyuplai daya-daya ke kilang dan utilitasnya. Keempat generator set ini juga tidak langsung dioperasikan dan bekerja secara bersamaan, namun hanya satu yang dioperasikan dan tiga sisanya standby siap jika terjadi overload beban maupun dilakukannya pergantian operasi generator set. Beberapa komponen dari PLTD PPSDM Migas Meliputi:

\section{Mesin Penggerak Mula (Prime Mover)}


Prime mover merupakan peralatan yang mempunyai fungsi menghasilkan energi mekanis yang diperlukan untuk memutar rotor generator. Mesin diesel sebagai penggerak mula PLTD berfungsi menghasilkan tenaga mekanis yang dipergunakan untuk memutar rotor generator.

\section{Starting Generator}

Genset yang digunakan oleh Power Plant PPSDM Migas Cepu memiliki daya yang lebih dari 500 kVA dan maksimum 1000 kVA. Sistem starting yang digunakan menggunakan battery 24 volt sebagai suplai listrik untuk menstart diesel. Saat start, generator DC mendapat suplai listrik dari battery dan menghasilkan torsi yang dipakai untuk menggerakkan diesel sampai mencapai putaran tertentu.

\section{Sistem Pelumasan (Lubricating System)}

Sistem pelumasan merupakan hal yang sangat penting dalam operasi suatu mesin. Beberapa fungsi dari sistem pelumasan adalah mengendalikan gesekan, mengendalikan suhu, mengendalikan korosi dan mengendalikan keausan.

\section{Sistem Penyaluran Bahan Bakar}

Dalam sistem penyaluran bahan bakar ini, PLTD PPSDM Migas Cepu memiliki tiga buah tangki yaitu tangki 401 sebagai tangki utama, tangki harian yang terletak di atas ruang mesin, dan Return tank adalah sebagai tangki yang menyalukan bahan bakar ke mesin diesel.

\section{Sistem Pendingin (Cooling System)}

Fungsi pendingin dari suatu mesin adalah untuk menjaga agar tidak menjadi panas berlebihan dari komponen-komponen mesin akibat panas pembakaran yang tinggi.

\section{B. Analisis Generator Set Diesel PLTD dan Bebannya}

\section{Generator Set Diesel PLTD}

Berikut data generator set PLTD yang ada di PPSDM Migas Cepu:

a. Generator 1 dan 8

Merk : Cummins

Kapasitas : 1000 KVA

Kecepatan : 1500 Rpm, Power Factor: 0.8

Tegangan : $380 \mathrm{~V}$, Frekuensi: $50 \mathrm{~Hz}$

b. Generator 2

Merk : Cummins 
Kapasitas : 1030 KVA

Kecepatan : 1500 Rpm, Power Factor: 0.8

Tegangan : $380 \mathrm{~V}$, Frekuensi: $50 \mathrm{~Hz}$

c. Generator Nomor 9

Merk : Cummins

Kapasitas : $640 \mathrm{KVA}$

Kecepatan : 1500 Rpm, Power Factor: 0.8

Tegangan : $380 \mathrm{~V}$, Frekuensi: $50 \mathrm{~Hz}$

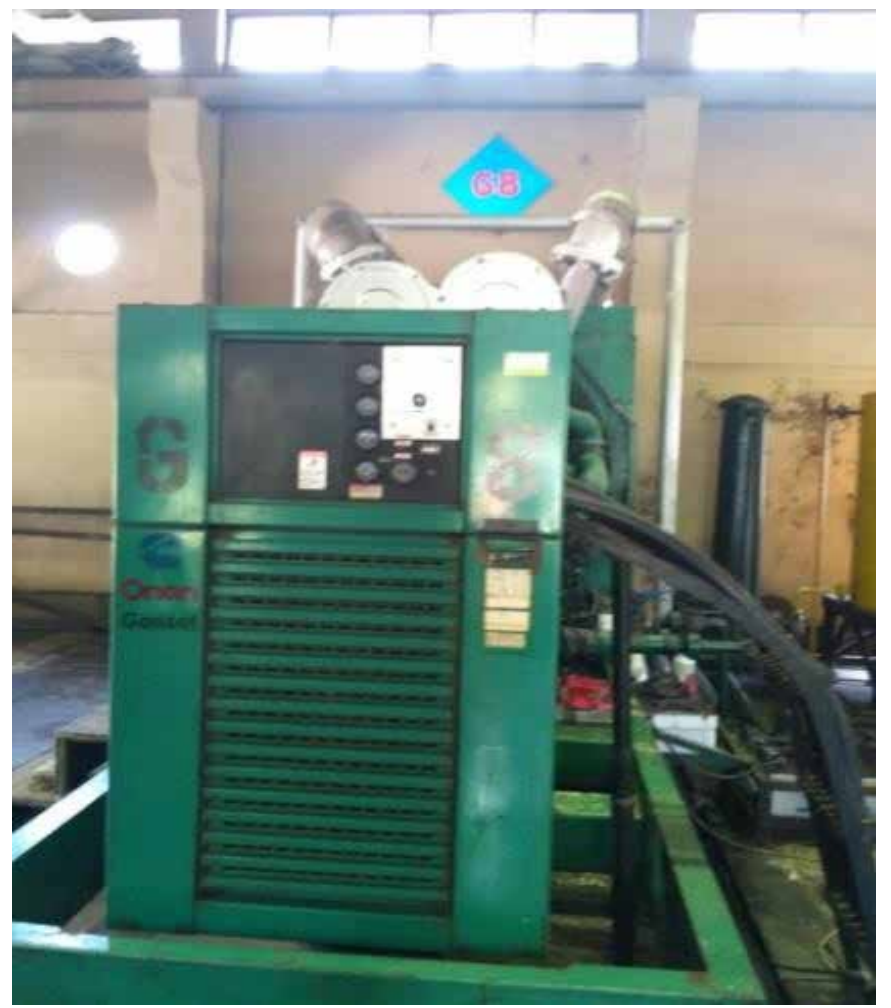

Gambar 1. Generator Set Cummins KTA 3865 di PLTD PPSDM Migas

Output daya yang dikeluarkan dari generator adalah sekitar $500 \mathrm{kw}$ yang dapat dilihat pada panel data generator set. Jika daya terlihat kurang memenuhi beban kilang dan utilitasnya, maka digunakan prinsip parallel dengan menghidupkan dua generator cadangan lagi untuk memenuhinya. Beban puncak yang terjadi tidak lebih dari $350 \mathrm{~kW}$, sehingga beban sebesar itu cukup dilayani dengan mengoperasikan 1 unit genset, terkecuali saat-saat tertentu baru dioperasikan 2 unit secara paralel. Berdasarkan data dari operator, untuk mengukur generator kuat tidaknya menerima beban dapat dilihat dari suhu generator yang overheating. Jika generator overheating maka dilakukanlah parallel 2 mesin selajutnya. Sedangkan untuk cara memindah- 
kan mesin satu ke mesin lainnnya, yakni dengan menghidupkan dahulu mesin kedua kemudian paralelkan dari mesin 1 ke 2, pindahkan beban 1 ke 2 secara perlahan.

\section{Analisis Beban Pada Kilang dan Utilitasnya}

Data beban yang berhasil dihimpun adalah sebagai berikut:

Tabel 1. Beban Daya Kilang dan Utilitasnya

\begin{tabular}{|c|c|c|c|c|}
\hline No & Beban & Daya $(k W)$ & Hours & Total kW/h \\
\hline 1 & Mesin motor proses 1 & 30 & 24 & 720 \\
\hline 2 & Mesin motor proses 2 & 30 & 24 & 720 \\
\hline 3 & Mesin motor proses 3 & 30 & 24 & 720 \\
\hline 4 & Mesin motor reflux & 15 & 24 & 360 \\
\hline 5 & Pompa distribusi 1 & 15 & 24 & 360 \\
\hline 6 & Pompa distribusi 2 & 15 & 24 & 360 \\
\hline 7 & Pompa distribusi 3 & 12,5 & 24 & 300 \\
\hline 8 & Pompa distribusi 4 & 28 & 24 & 672 \\
\hline 9 & Pompa distribusi 5 & 45 & 24 & 1080 \\
\hline 10 & Pompa distribusi 6 & 45 & 24 & 1080 \\
\hline 11 & Pompa distribusi 7 & 45 & 24 & 1080 \\
\hline 12 & Pompa distribusi 8 & 45 & 24 & 1080 \\
\hline 13 & Pompa steam 1 & 11 & 24 & 624 \\
\hline 14 & Pompa steam 2 & 11 & 24 & 624 \\
\hline 15 & Pompa steam 3 & 11 & 24 & 624 \\
\hline 16 & Kipas & 9 & 24 & 216 \\
\hline 17 & Motor utama & 45 & 24 & 1080 \\
\hline 18 & Motor sekunder & 9 & 24 & 216 \\
\hline 19 & Pompa air 1 & 50 & 20 & 1000 \\
\hline 20 & Pompa air 2 & 50 & 20 & 1000 \\
\hline 21 & Pompa air 3 & 37 & 20 & 740 \\
\hline 22 & Pompa air 4 & 37 & 20 & 740 \\
\hline 23 & Pompa air 5 & 132 & 20 & 2640 \\
\hline 24 & Pompa air 6 & 132 & 20 & 2640 \\
\hline 25 & Pompa air 7 & 132 & 20 & 2640 \\
\hline 26 & Pompa dari kolam 1 & 50 & 24 & 1200 \\
\hline 27 & Pompa dari kolam 2 & 45 & 24 & 1080 \\
\hline 28 & Pompa dari kolam 3 & 55 & 24 & 1320 \\
\hline 29 & Pompa dari kolam 4 & 50 & 24 & 1200 \\
\hline 30 & Pompa dari kolam 5 & 50 & 24 & 1200 \\
\hline 31 & Pompa dari sungai 1 & 55 & 24 & 1320 \\
\hline
\end{tabular}




\begin{tabular}{|c|l|c|c|c|}
\hline No & Beban & Daya $(\mathbf{k W})$ & Hours & Total kW/h \\
\hline $\mathbf{3 2}$ & Pompa dari sungai 2 & 62 & 24 & 1488 \\
\hline $\mathbf{3 3}$ & Pompa dari sungai 3 & 55 & 24 & 1320 \\
\hline $\mathbf{3 4}$ & Pompa pendingin 1 & 75 & 24 & 1800 \\
\hline $\mathbf{3 5}$ & Pompa pendingin 2 & 75 & 24 & 1800 \\
\hline $\mathbf{3 6}$ & Pompa pendingin 3 & 75 & 24 & 1800 \\
\hline $\mathbf{3 7}$ & Pompa pendingin 4 & 75 & 24 & 1800 \\
\hline $\mathbf{3 8}$ & Pompa pendingin 5 & 75 & 24 & 1800 \\
\hline $\mathbf{3 9}$ & Total Ac Kantor & 10 & 8 & 80 \\
\hline $\mathbf{4 0}$ & Penerangan kantor & 10 & 12 & 120 \\
\hline Total & & $1826 \mathrm{~kW}$ & & $42644 \mathrm{kWh}$ \\
\hline
\end{tabular}

Fakta di lapangan, beban-beban tersebut tidak semua beroperasi sesuai dengan table yang dihimpun oleh peniliti. Hal ini karena banyak beban seperti pompa air yang tidak bekerja, dan beberapa pompa-pompa pada kondisi real lapangan tidak bekerja. Seperti pompa pada pendingin, kolam, kilang, water treatment dan lainnya. Dan semua beban juga ada yang tidak bekerja dalam 24 jam. Sehingga beban-beban yang dihimpun oleh peneliti tersebut tidak sesuai dengan kondisi real lapangan yang ada. Sementara itu, melalui unit power plant, peneliti mendapatkan data actual lapangan sebagai berikut:

Tabel 2. Data Pemakaian Daya PLTD

\begin{tabular}{|l|c|c|c|c|c|}
\hline $\begin{array}{l}\text { Pemakaian } \\
\text { Beban }\end{array}$ & $\begin{array}{c}\text { Produksi Listrik } \\
\mathbf{( k W )}\end{array}$ & $\begin{array}{c}\text { Demand } \\
\text { Listrik } \\
\mathbf{( k W )}\end{array}$ & $\begin{array}{c}\text { Losses } \\
\mathbf{( k W )}\end{array}$ & Total kWh & $\begin{array}{c}\text { Efisiensi } \\
\mathbf{( \% )}\end{array}$ \\
\hline Januari & 186.51 & 171.589 & 14.921 & 186.51 & 91.99 \\
\hline Februari & 184.09 & 169.363 & 14.727 & 184.09 & 92.00 \\
\hline Maret & 186.066 & 171.181 & 14.885 & 186.066 & 92.00 \\
\hline April & 153.738 & 141.439 & 12.299 & 153.738 & 92.00 \\
\hline Mei & 179.04 & 164.717 & 14.323 & 179.04 & 92.00 \\
\hline Juni & 169.136 & 155.605 & 13.531 & 169.136 & 91.99 \\
\hline Juli & 160.07 & 147.264 & 12.806 & 160.07 & 91.99 \\
\hline Agustus & 178.84 & 164.533 & 14.307 & 178.84 & 92.00 \\
\hline September & 169.06 & 155.535 & 13.525 & 169.06 & 91.99 \\
\hline Oktober & 177.85 & 163.622 & 14.228 & 177.85 & 92 \\
\hline
\end{tabular}

Tabel 2. menunjukkan rekap data PLTD dari rentang bulan Januari sampai dengan Oktober 2020. Data tersebut merupakan produksi listrik yang di hasilkan oleh generator set diesel PLTD. Diamana data tersebut merupakan data bulanan dari unit power plant yang mengukur konsumsi daya output generator set dan juga daya demand dari kilang dan utilitasnya. Untuk mendapatkan data dia atas dengan melihat pada panel control yang ada di tiap generator set PLTD. Data tersebut didapat dengan cara membaca hasil posisi kWh yang ada di panel tiap- 
tiap generatornya. Setiap jamnya akan dicatat, berapa listrik yang dihasilkan dan diakumulasikan setiap hari dan bulannya.

Untuk mencari losses daya listrik yang terbuang pecuma dan efisiensi produksi daya listrik dari generator set PLTD. Dengan rumus persamaan sebagai berikut:

$$
\text { Losses }=\mathrm{PL}-\mathrm{DL}
$$

Sedangkan untuk mencari efisiensi produksi listrik dari generator set diesel PLTD, peneliti menggunakan rumus sederhana sebagai berikut:

$$
E P=\frac{D L}{P L} x 100
$$

\section{Dimana,}

Losses : Daya listrik yang terbuang percuma

EP : Efisiensi Produksi

DL : Demand Listrik

Dengan persamaan tersebut didapatkanlah grafik hasil sebagai berikut:

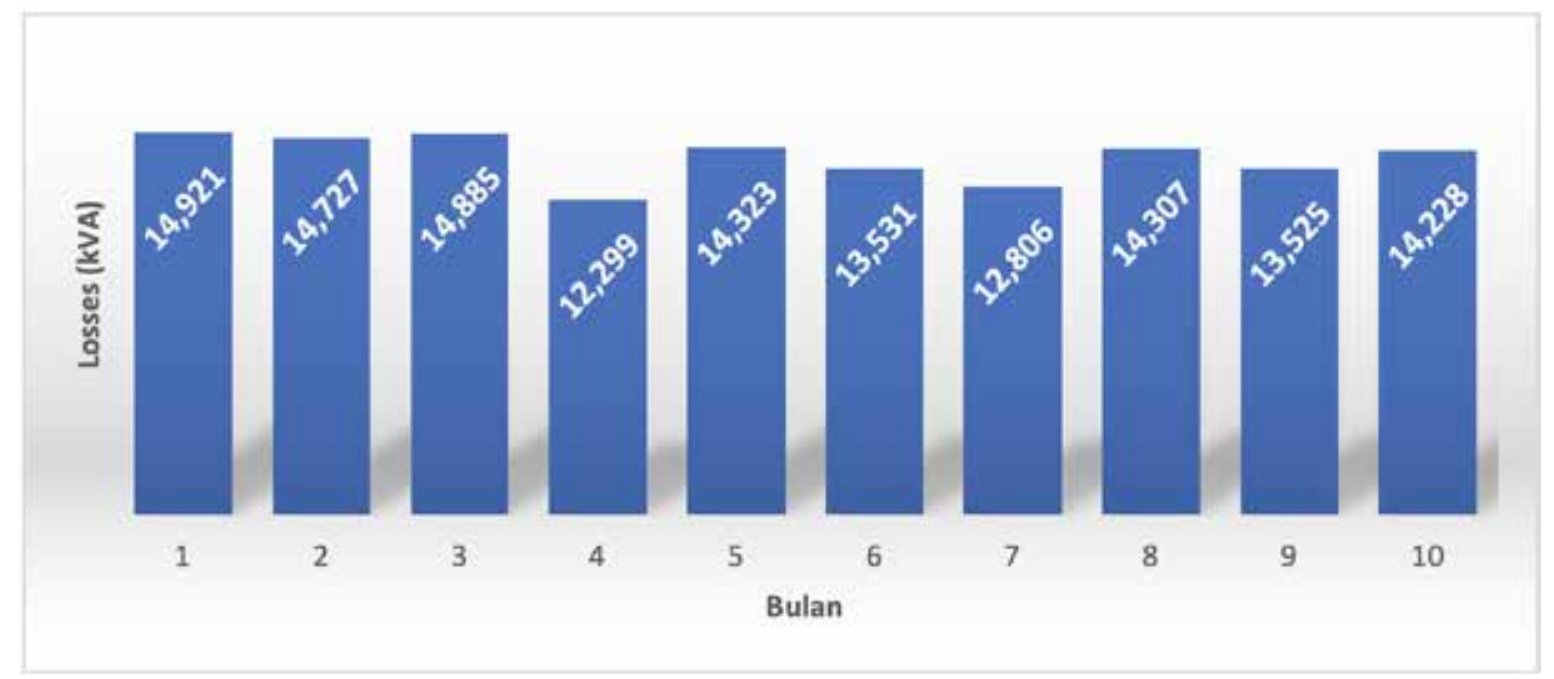

Gambar 2. Grafik Elestricity Losses 


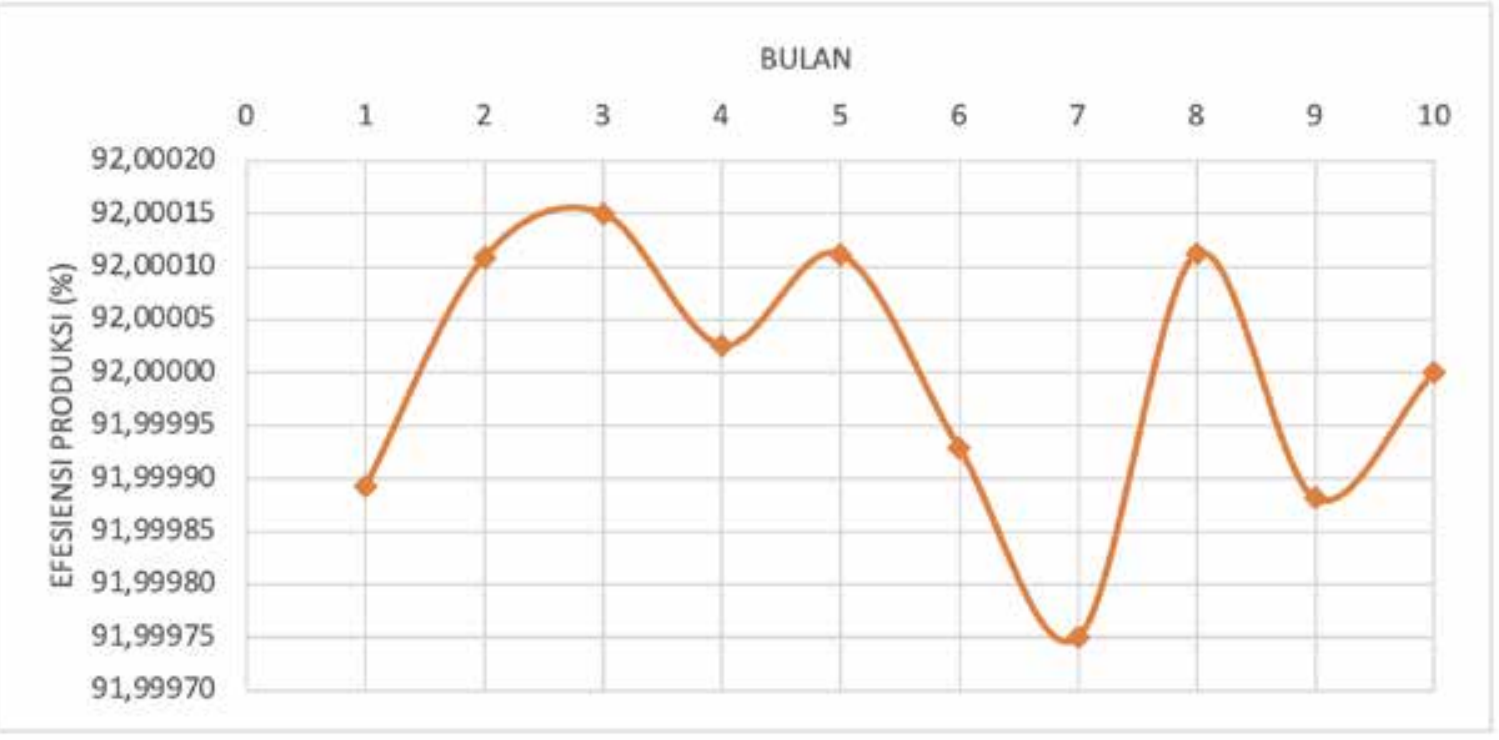

Gambar 3. Grafik Efisiensi Produksi

Dari grafik diatas terlihat jelas bahwa skema alur gerak dari data yang dihasilkan. Pada data losses daya, pada bulan april adalah performa yang paling bagus dengan kehilangan daya listrik tidak terpakai sebesar $12.299 \mathrm{~kW}$. Sedangkan losses terbesar terjadi pada bulan Januari dengan $14.921 \mathrm{~kW}$. Begitu juga dengan Efisiensi daya listrik generator set PLTD, performa paling bagus terjadi pada bulan Maret-Mei dengan Efisiensi rata-rata konstan di 92.00\%. Pada Efisiensi ini performa generator diesel bisa disimpulkan baik merata. Sebab, Efisiensi yang dihasilkan merata hampir sama.

\section{Analisi Konsumsi Bahan Bakar Generator Set Diesel PLTD}

\section{Konsumsi Bahan Bakar Harian dan $\mathbf{k W h}$}

Dari tabel 3. dapat kita lihat bahwa setiap satuan jamnya diukur berapa besar beban yang menjadi tanggungan dari generator set diesel PLTD. Pada table juga dapat dilihat beban puncak dan juga beban terendah atau base load.

Tabel 3. Konsumsi Bahan Bakar Harian

\begin{tabular}{|c|c|c|c|c|c|}
\hline \multirow{2}{*}{ Jam } & \multirow{2}{*}{ Beban Kw } & \multirow{2}{*}{ kWh } & \multicolumn{3}{|c|}{ Konsumsi BBM } \\
\cline { 4 - 6 } & & & $\begin{array}{c}\text { Tangki 1 } \\
(\mathbf{1 0 0} \text { liter })\end{array}$ & $\begin{array}{c}\text { Tangki 2 } \\
(\mathbf{1 0 0} \text { liter })\end{array}$ & $\begin{array}{c}\text { Tangki 3 } \\
(\mathbf{1 0 0} \text { liter) }\end{array}$ \\
\hline $\mathbf{9 : 0 0}$ & 360 & 451182 & 11.4 & 13 & 13.5 \\
\hline $\mathbf{1 0 : 0 0}$ & 300 & 451191 & 11.2 & 12.8 & 13.3 \\
\hline $\mathbf{1 1 : 0 0}$ & 270 & 451199 & 11 & 12.6 & 13.1 \\
\hline $\mathbf{1 2 : 0 0}$ & 230 & 451206 & 10.8 & 12.4 & 12.9 \\
\hline $\mathbf{1 3 : 0 0}$ & 220 & 451212 & 10.6 & 12.2 & 12.7 \\
\hline $\mathbf{1 4 : 0 0}$ & 250 & 451219 & 10.5 & 12.1 & 12.6 \\
\hline $\mathbf{1 5 : 0 0}$ & 220 & 451226 & 10.4 & 12 & 12.5 \\
\hline
\end{tabular}




\begin{tabular}{|c|c|c|c|c|c|}
\hline $\mathbf{1 6 : 0 0}$ & 220 & 451232 & 10.2 & 11.8 & 12.3 \\
\hline $\mathbf{1 7 : 0 0}$ & 210 & 451239 & 11.2 & 12.9 & 13.4 \\
\hline $\mathbf{1 8 : 0 0}$ & 220 & 451246 & 11 & 12.7 & 13.2 \\
\hline $\mathbf{1 9 : 0 0}$ & 310 & 451254 & 10.9 & 12.5 & 13 \\
\hline $\mathbf{2 0 : 0 0}$ & 220 & 451263 & 10.7 & 12.3 & 12.8 \\
\hline $\mathbf{2 1 : 0 0}$ & 260 & 451270 & 10.5 & 12.1 & 12.6 \\
\hline $\mathbf{2 2 : 0 0}$ & 220 & 451277 & 10.3 & 12 & 12.5 \\
\hline $\mathbf{2 3 : 0 0}$ & 220 & 451281 & 10.1 & 11.8 & 12.3 \\
\hline $\mathbf{0 : 0 0}$ & 300 & 451290 & 10 & 11.6 & 12.1 \\
\hline $\mathbf{1 : 0 0}$ & 220 & 451297 & 11.3 & 12.9 & 13.4 \\
\hline $\mathbf{2 : 0 0}$ & 240 & 451304 & 11.1 & 12.7 & 13.2 \\
\hline $\mathbf{3 : 0 0}$ & 230 & 451310 & 10.9 & 12.6 & 13.1 \\
\hline $\mathbf{4 : 0 0}$ & 250 & 451317 & 10.7 & 12.4 & 12.9 \\
\hline $\mathbf{5 : 0 0}$ & 270 & 451324 & 10.5 & 12.2 & 12.7 \\
\hline $\mathbf{6 : 0 0}$ & 260 & 451332 & 10.3 & 12 & 12.5 \\
\hline $\mathbf{7 : 0 0}$ & 290 & 451340 & 10.1 & 11.8 & 12.3 \\
\hline $\mathbf{8 : 0 0}$ & 290 & 451349 & 9.9 & 11.6 & 12.1 \\
\hline
\end{tabular}

Sehingga dari table tersebut maka dibuatlah kurva konsumsi bahan bakar harian sebagai berikut:

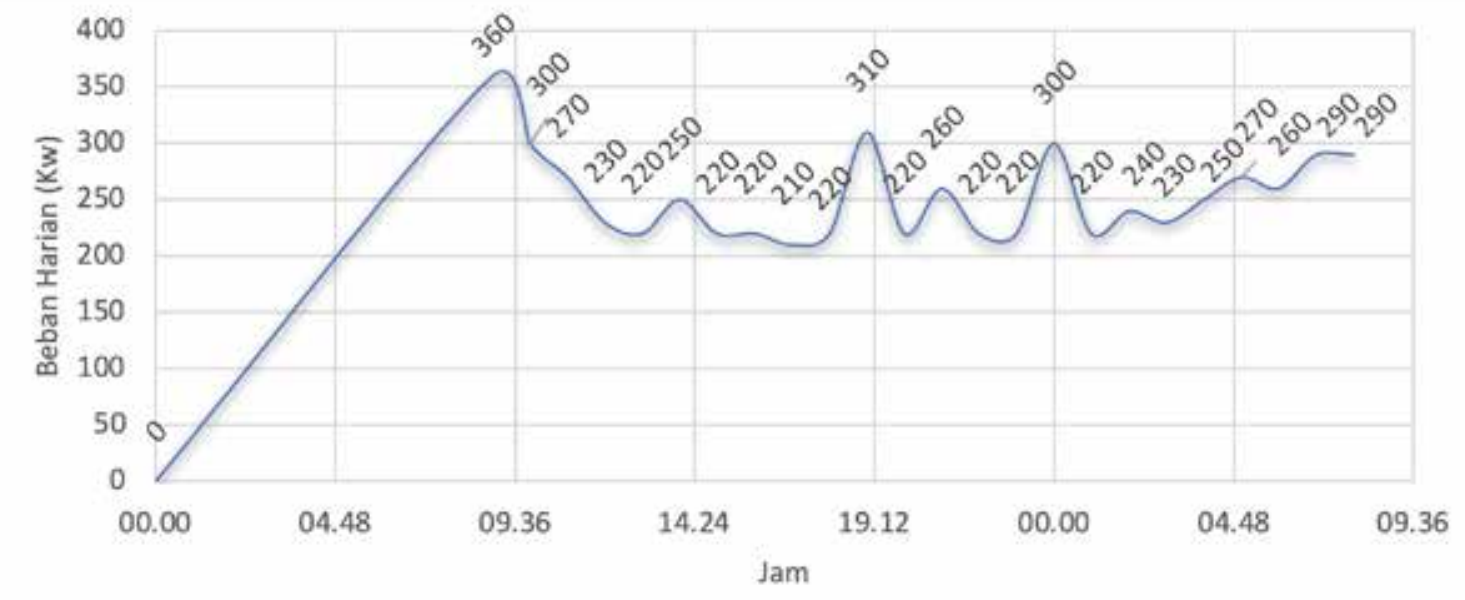

Gambar 4. Kurva Beban Harian (kW)

Dari data di atas terlihat juga bahwa pada pukul 09.00 merupakan beban puncak dengan beban sebesar $260 \mathrm{~kW}$ dan base load atau beban terendah pada beban $220 \mathrm{~kW}$. Dari sini kita dapat menghitung daya input dengan persamaan berikut:

$$
\begin{aligned}
& \text { DayaInput }=\frac{1}{0.7} \times \text { Baseload } \\
& \text { DayaInput }=\frac{1}{0.7} \times 220
\end{aligned}
$$




$$
=314.29 \mathrm{~kW} \text { atau } 392.86 \mathrm{kVA}
$$

Sehingga dari beban puncak dapat dipilih

$$
\frac{360 \mathrm{~kW}}{314.2 \mathrm{~kW}}=1 \text { unitdiesel }=@ 392.86 \mathrm{kVA}
$$

Dengan demikian, dari hitungan di atas dapat kita artikan bahwa beban yang menjadi tanggungan pada hari tersebut masih sesuai. Jika beban yang menjadi tanggunagan mencapai 500 kW maka mesin generator set diesel PLTD harus di parallel. Dengan data tersebut juga dapat disimpulkan bahwa semakin kecil range (gap) antara pembebanan maksimum dan minimum maka akan semakin optimal kinerja dari sebuah mesin diesel. Dalam pengukuran bahan bakar ini, ada tiga shift pergantian operator. Disetiap shift pergantiannya bahan bakar akan diisi kembali. Besaran pengisian dilakukan sebesar lebih kurang 350 liter solar. Kemudian akan dihimpun dan dicatat oleh operator perkembangan bahan bakarnya.

Dari tabel 3. di atas dapat dilihat bahwa warna pada tabel merupakan ketiga shift pergantian operator. Data nilai pada tabel tersebut berdasar informasi dari operator dikalikan dengan 100 liter. Untuk menghitung konsumsi bahan bakarnya adalah dengan cara mencari selisih dari posisi awal bahan bakar dikurang posisi akhir bahan bakar pada setiap shiftnya sebelum diisi ulang. Dicari hingga shift terakhir. Sehingga akan didapatkan selisih konsumsinya per setiap shift jaga.

Dapat diketahui bahwa total dari semua selisih bahan bakar yang terpakai pada tangki 1 adalah 3800 liter, tangki 2 adalah 3800 liter dan tangki 3 juga 3800 liter. Sehingga total konsumsi bahan bakar dalam 24 jam atau per harinya yakni tangki $1+\operatorname{tangki~} 2+\operatorname{tangki} 3$ adalah 1140 liter solar. Sementara itu untuk konsumsi per kWh adalah berikut:

$$
\begin{aligned}
& \text { Konsumsi } / k W h=\frac{\text { Konsumsi bahan bakar per jam }}{(\text { Beban } k W h \text { Akhir }- \text { Beban } k W h \text { Awal })} \\
& \text { Konsumsi } / k W h=\frac{(1140 / 24)}{(451349-451182)}
\end{aligned}
$$$$
\text { Konsumsi } / \mathrm{kWh}=\frac{47.5}{167}=0.2844 \text { liter } / \mathrm{kWh}
$$

Sehingga konsumsi bahan bakar per kWh pada generator set PLTD PPSDM Migas Cepu yaitu berkisar rata-rata 0.28 liter $/ \mathrm{kWh}$ yang diambil data pada hari tersebut.

\section{Estimasi Konsumsi Bahan Bakar Bulanan}

Dalam penelitian ini juga peneliti mendapatkan data dari operator unit power plant terhadap data bulanan konsumsi bahan bakar generator set diesel PLTD. Dengan data sebagai berikut: 
Tabel 4. Data Konsumsi Bulan Januari-Oktober

\begin{tabular}{|l|c|c|c|}
\hline Bulan & Produksi kWh & Konsumsi BBM (L) & Pemakaian Solar /kWh \\
\hline Januari & 186,510 & $58,082.80$ & 0.311419227 \\
\hline Febuari & 184,090 & $56,066.50$ & 0.304560269 \\
\hline Maret & 186,066 & $58,964.30$ & 0.316899917 \\
\hline April & 153,738 & $50,648.10$ & 0.329444249 \\
\hline Mei & 179,040 & $57,668.90$ & 0.322100648 \\
\hline Juni & 169,136 & $54,477.90$ & 0.322095237 \\
\hline Juli & 160,070 & $52,667.40$ & 0.329027301 \\
\hline Agustus & 178,840 & $61,672.10$ & 0.344845113 \\
\hline September & 169,060 & $54,837.60$ & 0.32436768 \\
\hline Oktober & 177,850 & 59,662 & 0.335462468 \\
\hline Total & $1,744,400$ & $564,747.60$ & \\
\hline
\end{tabular}

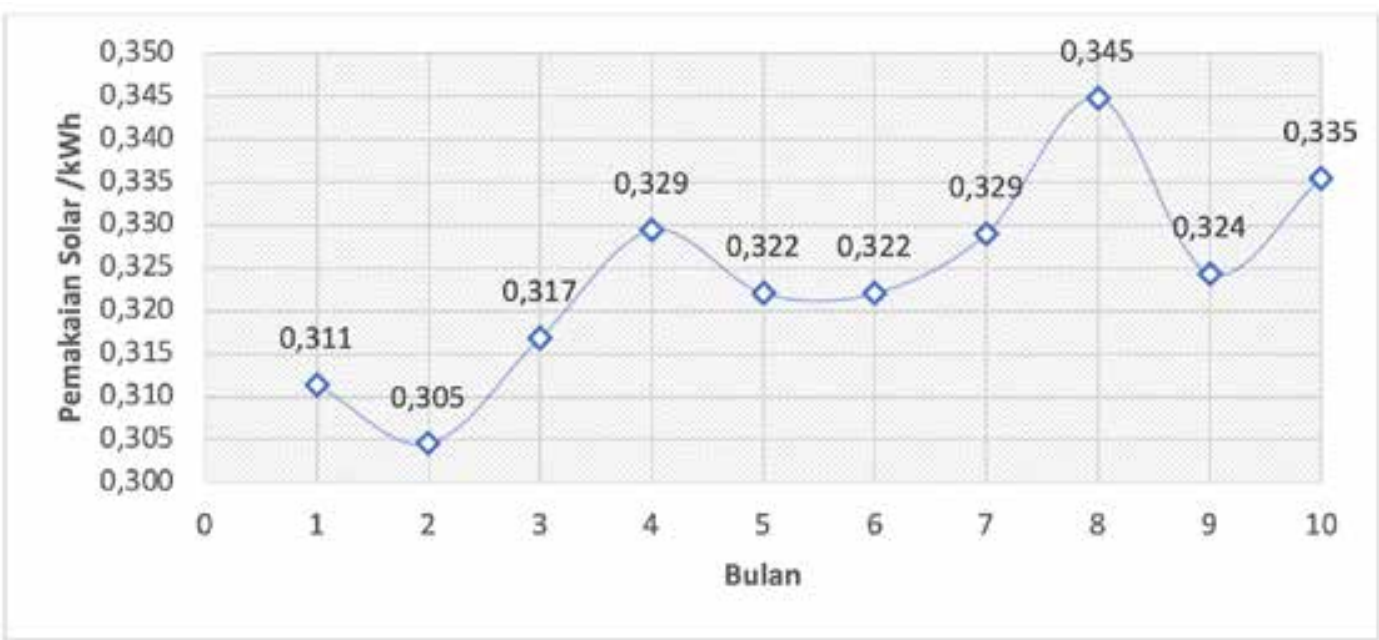

Gambar 5. Pemakaian Solar/kWh Bulan Januari-Oktober

Dari grafik tersebut jika dilihat konsumsi bahan bakar tertinggi terjadi pada bulan Agustus dengan konsumsi 0.344845113 liter solar/kWh dan konsumsi terendah terjadi pada bulan Februari dengan konsumsi 0.304560269 liter solar/kWh.

Sementara itu konsumsi solar ini juga tergantung dari operasi mesin gensetnya. Untuk operasi gensetnya sendiri memiliki jadwal tersendiri seperti contoh pada Bulan Oktober, genset 2 bekerja selama 167 jam kemudian dipindah ke genset 1 dengan total operasi 313 jam pada 18 Oktober dan dilakukan maintenance 250 jam, genset 8 total bekerja selama171 jam pada 26 Oktber dan genset 1 total bekerja selama 239 jam pada 31 Oktber. Sedangkan pada Bulan November baru dilakukan 250 jam maintenance pada 4 November 2020. 


\section{Kesimpulan}

Berdasarkan hasil pengamatan langsung dan perhitungan, diketahui bahwa unit power plant PLTD PPSDM Migas Cepu memiliki 4 mesin diesel generator set, yakni mesin G1, G2, G8 dan G9 yang bertugas menyuplai daya ke kilang dan utilitasnya. Jika beban melebihi kapasitas untuk 1 generator, maka generator cadangan siap diparralel kan. Semua beban yang yang ada di unit kilang dan utilitasnya tidak bekerja bersamaan. Sehingga mesin genset masih bekerja optimal dengan catatan Jika semua beban tidak hidup bersamaan, jika hidup bersamaan maka bebanya terlalu besar dan tidak kuat untuk genset PLTD.

Pembebanan yang terjadi di Kilang dan utilitas bervariasi tiap waktunya, pembebanan tertinggi pada periode tahun 2020 terjadi pada bulan Januari sebesar $171.589 \mathrm{~kW}$. Pembebanan yang dapat diterima pada satu genset yang ada di PLTD PPSDM Migas Cepu maksimal hanya 3/4 dari pembebadan maksimumnya yaitu sekitar $375 \mathrm{~kW}$, jika pembebanan lebih dari itu genset akan diparalelkan ke genset lainnya untuk membagi pembebanan yang diterima dari kilang dan utilitasnya. Sementara itu, untuk konsumsi bahan bakar, dalam 24 jam atau per harinya yakni tangki 1, tangki 2 dan tangki 3 adalah 1140 liter solar. Sedangkan untuk konsumsi per kWh adalah 0.2844 liter/kWh. Dalam hal ini dapat disimpulkan juga bahwa mesin generator set diesel masih bekerja secara optimal dengan efisiensi losses nya merata 92\%. Usaha preventif dari operator untuk mencegah adanya kerusakan. Pada akhirnya perawatan dan maintenance dari PLTD itu sendiri sangat menentukan performa dari generator set dieselnya supaya tetap bekerja dengan optimal dan dalam jangka waktu yang panjang.

\section{Daftar Pustaka}

Badaruddin, B., \& Hardiansyah, F. (2015).Perhitungan Optimasi Bahan Bakar Solar Pada Pemakaian

Generator Set Di BTS. Jurnal Teknologi Elektro, 6(2).

Wijana, M.,Triadi, A. A., \& Anwar, L.S. (2016). Studi Kelayakan Penggunaan Mesin Diesel Dengan Motode

Break Even Point (BEP) dan Analisis Sensitivitas Pada PLTD (Studi Kasus: PT PLN Persero Sektor

Pembangkit Lombok PLTD Ampean). Dinamika Teknik Mesin, 6(1). 